\title{
THE EMERGENCE AND DEVELOPMENT OF SPACE PSYCHOLOGY IN POLAND. THE SIGNIFICANCE OF HISTORICAL SPACE FLIGHT OF MIROS $Ł A W$ HERMASZEWSKI
}

\author{
Jan F. Terelak \\ Department of Flight Safety, Military Institute of Aviation Medicine \\ Chair of Occupational and Stress Psychology, Institute of Psychology, Cardinal Stefan Wyszyński University in Warsaw \\ Author's address: J.F. Terelak, Military Institute of Aviation Medicine, Department of Flight Safety, Krasińskiego 54/56 Street, \\ 01-755 Warsaw, Poland, e-mail: jterelak@wiml.waw.pl
}

Source of support: Own sources

Introduction: This article is an review attempting to assess the achievements of space psychology in Poland since the establishment and development of the discipline inspired by the historical space flight of the first Pole, Maj. Mirosław Hermaszewski.

Methods: Polish and worldwide literature in aviation and space psychology was reviewed in a retrospective and prospective manner.

Results: Four key areas of interest of Polish space psychology were identified: (1) model for psychological selection of Polish cosmonauts; (2) Polish psychological studies conducted in the space station; (3) Studies in the natural laboratory of the Arctic and Antarctic Stations of the Polish Academy of Sciences; (4) Popularization activities related to space psychology in Poland.

Discussion: Elements common for both American and Soviet (Russian) space psychology were identified in examinations of cosmonauts and astronauts; the original Polish input to the worldwide literature on the subject was highlighted.

Conclusions: The historical space flight of the first Pole had undoubtedly had a strong impact on the establishment and development of many space-related scientific disciplines, including space psychology.

Keywords: pilots, astronauts, cosmonauts, astronautics, extreme stress, psychological selection criteria for space mission crew members

Figures: 2 - Tables: 2 - References: 98 • Full-text PDF: http://www.pjamp.com • Copyright (C 2013 Polish Aviation Medicine Society, ul. Krasińskiego 54/56, 01-755 Warsaw, license WIML • Indexation: Index Copernicus, Polish Ministry of Science and Higher Education 


\section{INTRODUCTION}

The article attempts to assess the achievements of space psychology in Poland since the establishment and development of the discipline inspired by the historical space flight of the first Pole, Maj. Mirosław Hermaszewski. The analysis is retrospective and prospective with regard to the model of psychological selection of Polish candidates for space flights compared to the models in use in the US and the USSR (Russia) as well as to experiments conducted in natural conditions of space stations and the polar stations of the Polish Academy of Sciences in the Arctic and the Antarctic.

In the 1980s, space research was conducted within two international organizations: NATO and Interkosmos. Polish space psychology was established on the basis of aviation psychology in relation to the space flight of the first Pole planned for 1978 as part of the international Interkosmos program co-ordinated by the USSR. The program, established by the state academies of sciences of the communist block countries, included operation of a so called Working Group co-ordinating research in various disciplines; human sciences were grouped under the problem titled "Space biology and medicine", which included the sections of radiobiology, physiology and space psychology. The main task of the space psychology section was to develop the criteria for selection of candidates for space flights, to prepare appropriate psychological tests as well as to monitor the psychological welfare of cosmonauts during the space flight (e.g. acute and long-term adaptation to zero gravity conditions, etc.) and its consequences following the return to the Earth.

Since the very onset of the idea of sending a man into the space, was one of the basic problems, together with the general health of the cosmonauts, was their psychological fitness. Space medicine, part of which is space psychology, has borrowed its baseline models from aviation medicine, as the main task of the first cosmonauts was to pilot the spaceships and the best candidates for the task were recruited from preselected professional military pilots characterized by good health, high intelligence and resistance to stress. Two main centers conducting tests of candidates for space flights, expertise of which laid the foundation for Polish space medicine and psychology were located in the US and the USSR. Despite numerous similarities in the methodology of studies, there were also some differences in the selection criteria and the particular methods of psychological selection; they are worth attention.

\section{METHODS}

The methods for psychological selection of candidates for space flights were a consequence of the adopted model of a future cosmonaut or astronaut ${ }^{1}$. Aviation physicians and psychologists involved in Project Mercury in the US have developed selection criteria for astronauts to take part in the flights in Mercury space vessels as early as in 1958 [42]. The criteria included health-related, psychological and methodological indications. The first group of 35 candidates was selected from active jet plane pilots, comprising a target sample to be later subjected to a two-stage selection. The first stage of psychological tests involved classical pen-and-paper tests to assess the fluid and functional intelligence and mathematical/technical skills. In addition, psychiatric/psychological interviews were conducted with the purpose of eliminating 13 predefined psychopathological personality symptoms [29].

At this stage, several candidates were eliminated and the selection progressed into the second stage performed using the research and clinical base of an aviation medicine institute. Structured psychological interviews and personality tests were employed at this stage. The described selection procedure pertained particularly to military pilots whose task was mainly to pilot the space vessels (pilots, navigators, board engineers). The first experiences from American space flights conducted as part of Project Mercury confirmed the aptness of medical and psychological criteria for selection of military pilots. The assessment included not only economical and political criteria (reduced secondary selection time and high morale, respectively), but also those related to health (all candidates had valid health certificates) and psychological condition (psychomotor habits, resistance to stress, lack of psychopathological symptoms) [42].

In the 1960s, NASA developed four more programs of selection of astronaut researchers (scientists) coming from more diverse backgrounds. This was due to the need to select space crews consisting of several individuals as planned for NASA's subsequent space programs Gemini and, particularly Apollo. Despite intellectual capabilities, psychological tests were largely focused on pro-social personality features consisting of interpersonal skills and emotional stability. Besides

\footnotetext{
1 The difference between term „astronaut” as used in the US and "cosmonaut" as used in the USSR and currently in Russia is due to political and not scientific reasons. To date, no human being had ever been in the open space (cosmos) outside the Solar System, all the more, no human being has ever been en route to the stars (astra).
} 
batteries of personality tests, detailed biographical, professional background and psychiatric interviews were carried out [46]. Psychological tests were autonomous in nature, although the psychologists took part in interdisciplinary (medical/ engineering) committees.

As astronautics developed in the direction of long-term space flights in space stations, selection tests were complemented with tests conducted in laboratory conditions (e.g. artificial ground habitats) as well as in natural conditions (polar stations, drifting floes, submarines etc.) to assess the health and psychological consequences of longterm sensory or social deprivation. Currently, such studies are conducted from viewpoint of future interplanetary flights (e.g the Moon, Mars). However, the most important studies pertained to the impact of zero gravity conditions on physiological and psychological functions of humans [10.98].

In the Soviet Union, selection of candidates for space flights in the first period in the development of cosmonautics was based on the "engine operator" model, with much importance being attached to psychomotor agility. As cosmonautics developed and new tasks were defined, the methods initially established in military aviation medicine were modified to reflect more complex models based on the psychology of personality, social psychology and stress psychology as professionally diverse crews were to be selected for long-term flights in space stations [35]. In general, the structure of the selection process consisted of three stages: (1) ambulatory stage - as in the case of American astronauts, this stage involved the psychiatric diagnosis of evident functional disorders constituting explicit contraindications for space flights [26]; (2) stationary stage including the diagnoses made in static (psychological tests) and dynamic conditions (simulators) with regard to occult functional disorders and determination of bodily reserves to adapt to extreme conditions [52]; and (3) training stage to assess both physical efficiency in extreme training conditions (e.g. alpine, marine, desert conditions) and resistance to isolation and danger-related stress (e.g. far-sea, undersea, polar conditions) [39]. Psychological tests that constituted an integral part of medical examinations were conducted mainly at the second, stationary stage and included clinical and community interviews, psychological personality tests, intelligence and psychomotor agility tests and the assessment of the ability to learn new tasks. In addition, candidates for crew flights were subjected to interpersonal training (experiments) with respect to the dynamics of small task teams in artificial working environments.

The Polish model for psychological selection of candidates for space flights included both the psychometric elements adapted from the American model $[1,20]$, and the dynamic (performance) aspects of the Russian model [35,37].

The point of departure for the development of the procedure of psychological studies was the so-called pilot's psychological profile that included the requirements regarding optimum management of operational risks, psychophysical fitness and situational awareness that depended on such individual-related resources as general health, cognitive capabilities, personality, operator skills, etc. [88], resistance to workload and fatigue [50] as well as the ability to cope with stress associated with piloting aircraft [92].

This test procedure was based on the experience of aviation medicine and psychology related to the recruitment of candidates for military aviation [55]. The procedure consisted of the following stages: initial interview (biography/professional data), analysis of documents, medical examinations, psychological tests, physical efficiency tests (in simulators and real life conditions), professional tests, trial period (mastering of tasks subject to examinations), final negative or positive diagnosis. Partial diagnoses were made at each stage. A negative partial diagnosis eliminated the candidate from subsequent stages while the positive diagnosis constituted a pass to further examinations.

Thus, the psychological assessment, autonomous in character, was a part of a complex procedure for selection in space flight candidates and involved several examination steps [73]. The first step was a negative diagnosis consisting in elimination of psychopathological symptoms based on structured clinical interviews and the Minnesota Multiphasic Personality Inventory (MMPI) of 567 questions (with answers "true", "false" or "don't know") constituting three validity scales, ten clinical scales and several dozens subscales. Validity scales describe personality defense mechanisms while the $\mathrm{F}-\mathrm{K}$ scale index provides information about simulation/dissimulation tendencies (aka lie factor). Clinical scales cover the following psychopathological aspects: (1) Hd - Hypochondriasis (including psychosomatic disorders); (2) D-Depression (subjective depression, psychomotor retardationb, mental numbness, etc.); (3) Hy - Hysteria (denial of social fears, somatic complaints, etc.); (4) Pd - Psychopathic Deviations (family conflicts, attitude towards authorities, social alienation); (5) MF - Masculinity/femininity (disturbance of sexual identity, 
narcism, heterosexual discomfort, etc.); (6) Pa - Paranoia (the level of paranoidal disorders, persecutive ideations, etc.); (7) Pt - Psychastenia (generalized neurosis); (8) Sc - Schizophrenia (schizophrenic disorders on neurotic or psychotic background); (9) Ma - Hypomania (hypomanic and manic disorders); (10) Si - Social introversion (withdrawal from social life, timidity, etc.). Supplemental scales include: A anxiety scale; R - repression scale; MAS - manifest anxiety scale; Es - Ego strength scale; Re - responsibility scale; St - social status scale; $\mathrm{Cn}$ - control of psychopathology scale; MAC - MacAndrews alcoholism scale; R-S - repression-desensitization scale. Results in individual clinical scales facilitate elimination of candidates with psychopathological traits.

The next stage of psychological tests consisted in determination of personality profiles for space flight candidates. A personality model was adopted that consisted of the following components: personality structure and resistance to stress, motivation level, intelligence quotient and psychomotor agility

Personality structure was determined on the basis of the Sixteen Personality Factor Questionnaire (16PF) by R.B. Cattell, consisting of 368 questions and 16 following binary scales (+/-): A - schizothymia/afectothymia (emotional cautiousness vs. openness); B - intelligence (low vs. high); C - emotional stability/instability; E - dominance/submissiveness; F - surgency (openness to social contacts/desurgency (social isolation); $\mathrm{G}$ - character strength/listlessness; $\mathrm{H}$ - boldness/ timidity, I - emotional sensitivity/roughness; L trustfulness/distrustfulness; $M$ - practicality/unconventionality; $\mathrm{N}$ - naivety/shrewdness, $\mathrm{O}$ - selfassured/self-doubting, Q1 - conservatism/radicalism; Q2 - self-reliance/dependence on others; Q3 - personal integrity/lax; Q4 - placidity/tenseness. The personal profile of each candidate for a cosmonaut was compared to the standard profiles of jet planes [70].

Besides the 16PF questionnaire, the surveys performed as part of the process of selection of space flight candidates included the Eysenck Personality Questionnaire (EPQ) to assess such binary personality traits as extroversion/introversion, neuroticity (+/-) and the social approval variable and Taylor's Manifest Anxiety Scale (MAS) at the self-assessment level together with the measurement of heart rate upon catapulting in ground conditions at the physiological level. The last two tests were used to assess the resistance to the danger-related stress as a temperamental personality trait.
At the third stage of psychological tests, motivation behind the decision to become a candidate for space flight was tested on the basis of structured psychological interview and MMPI's Gough index, defined as the difference in the F-K validity scales (raw data) and indicative of individual's tendency to simulate (Gough $>14$ or $F \geq 70$ ) or dissimulate (Gough $<-8$ or $\mathrm{K} \geq 70$ ). All Polish candidates for cosmonauts demonstrated a high tendency to dissimulate, i.e. to present oneself in better light, which was considered to be an indication of high motivation as correlated with data from psychological interviews.

At the fourth stage of the tests, the intelligence quotient (IQ) was assessed in the Wechsler Adult Intelligence Scale (WAIS), consisting of verbal, performance and vocabulary scales. Verbal scale consists of information, number sequencing, arithmetics, comprehension, similarity and vocabulary tests. Performance scale consists of picture completion, picture ordering, block designs, matrix reasoning and digit symbol-coding. Wechsler scale allows to assess the verbal and non-verbal IQ. Fluid intelligence was assessed using the standard Raven's progressive matrix test consisting of 5 scales (A, B, C, D, E) of increasing difficulty. Each scale is comprised of 12 tasks consisting of detecting relationships between the elements of a pattern (matrix) and identifying the missing elements in a .presented matrix. The test is used to diagnose the non-verbal intelligence independent of the subject's experience, education, background etc. It allows to assess individual's capability of logical induction, perception of pattern continuity (scale A), analogies between pairs of symbols (scale B), progressive changes of patterns (scale C), symbol reordering (scale D), and decomposition of symbols into elements (scale E).

The fifth stage consisted of perception/motor agility tests including pen-and-paper experiments, chronometers and various coordination meters to assess the time of simple and alternative reactions (to visual and acoustic signals) different aspects of operational memory and visual and auditory focus (capacity, divisibility, set-shifting and concentration), visual perception (acute vision from different distances, adaptation to varied lighting levels, biocular conversion of vision of single objects, sensitivity to light daze, distinguishing colors) [38]. Besides the agility ranks themselves, the diagnosis of psychomotor fitness included the analysis of interindividual differences due to different temperaments [89] or personalities $[83,84]$. 


\section{RESULTS}

The final diagnostic step involved the development of detailed psychological profiles based on the obtained test data. Superimposed on the profiles of all Polish jest plane pilots, the obtained profiles were used as the basis for the overall result ranking and recommendations for the interdisciplinary Qualification Committee of the Military Institute of Aviation Medicine in Warsaw. Table 1 presents one of such profiles namely the $16 \mathrm{PF}$ personality profile of Polish candidates for cosmonauts.

Based on the results of medical, psychological and efficiency studies, the committee has selected four (out of 60) Polish candidates for cosmonauts to undergo further selection in Zvezdnoy Gorodok (near Moscow), including training and space simulator exercises [2]. Finally, two out of four candidates were qualified for the space flight: maj. Mirosław Hermaszewski and his double, It. col. Zenon Jankowski.

Maj. Mirosław Hermaszewski took off for a space flight together with cosmonaut Col Pyotr Klimuk on June 27, 1978, at 5:27 p.m., on board of the Soyuz 30 spaceship. On June 28, 1978, at 7:08 p.m., Soyuz 30 docked at the space station Salyut 6 . The crew spent 126 orbital revolutions, lasting 190 hours, 3 minutes and 4 seconds and covering the distance of $5273257 \mathrm{~km}$. Having completed the research program, cosmonauts landed in Kazakhstan steppes on July 5th, 1978. The flight has offered Polish researchers in space medicine and psychology an opportunity to conduct research on board

Tab. 1. Overall personality profile of Polish pilot candidates for space flights $(n=60)$ as assessed by the 16PF questionnaire by R.B. Cattell (Terelak, 1976). of the space station, thus establishing space medicine and psychology in Poland.

Starting from the international orbital space station flights, Moon landings and the development of plans of a manned flight to Mars, space psychology research focused on the analysis of conditions of operation in zero gravity conditions, the assessment of psychological costs of longterm social isolation, and on the assessment of abilities to cope with stress, particularly associated with long space flights. Table 2 lists the sources of psychological stress during space flights.

The aforementioned problems have been discussed in more detail in e.g. E.K.E. Gunderson [18], J.H. Earls [14], J.M. Christensen, J.M., Talbot [9], J. Terelak, O. Truszczyński [94,95], J.B. West [98], V.A. Concertino [10] and others.

\section{Studies in natural conditions - space station laboratory}

When analyzing the developmental trends of Polish aviation and space psychology in professional literature $[68,74,86]$ against the achievements of space psychology worldwide $[87,94,95]$, the assessment of psychological well-being of cosmonauts in the space station [30] should be considered an important contribution. Polish psychologists developed the Medicopsychophysiological Questionnaire (Medikopsykhophizyologicheski Oprosnik) - a testing tool to monitor the well-being of cosmonauts before the takeoff, during the flight and the stay at the space station and

\begin{tabular}{|c|c|c|}
\hline Factor & Standardized result & Personality trait \\
\hline$(E+)$ Dominance & (9.2) & Dominant, aggressive, assertive \\
\hline$(\mathrm{H}+)$ Social boldness & (9.0) & Socially bold, venturesome, uninhibited \\
\hline (Q2+) Self-reliance & (7.9) & Resourceful, self-sufficient \\
\hline (C+) Emotional stability & (7.5) & Emotionally resistant to stress \\
\hline
\end{tabular}

Tab. 2. Sources of psychological stress in real-life space flight conditions or space flight analogs

\begin{tabular}{ll}
\hline \multicolumn{1}{c}{ Stress symptom } & \multicolumn{1}{c}{ Space mission/analog } \\
\hline 1. Homesickness & American and Soviet space missions, Antarctic bases [8,58] \\
\hline 2. Reduced motivation to work & Antarctic bases, Soviet space missions [17,18] \\
\hline 3. Transcendental experiences, sensory illusions & American and Soviet space missions [44] \\
\hline 4. Circadian rhythm disturbances & Space missions: Gemini, Apollo, Soyuz [31] \\
\hline 5. Aggressive behaviors & Space missions, Antarctic bases, submarines [14,18,41] \\
\hline 6. Closing in oneself, depression, mood swings & Polar bases [47,59] \\
\hline 7. Motor coordination disorders & American and Soviet space missions [11] \\
\hline 8. Conflicts in the space flight crew & American and Soviet space stations [12,40] \\
\hline
\end{tabular}


after completion of the space flight. According to the instructions, cosmonauts completed the questionnaire 8 times: (1) 24 hours before the takeoff (A1); (2) directly before the takeoff (A2); (3) during the first encirclement of the Earth (B1); (4) half through the space flight (B2); (5) during the space flight after completion of the task (B3); (6) directly after landing (C1); (7) 24 hours after landing (C2); and (8) one week after landing. In cases 1, 2, 6, 7 , and 8 cosmonauts answered a set of 9 questions, while in cases $3,4,5$, they answered a set of 51 questions, assessing their feelings using a scale from 0 to 100. The questionnaire was developed in Polish language version at the Military Institute of Aviation Medicine in Warsaw by Jan Terelak and Zdzisław Kobos and adapted to Russian language by Olga Kozerenko of the Institute of Biomedical Problems of the Russian Academy of Sciences in Moscow in two versions: a pen-and-paper version and an electronic version for IBM computers (XT, AT or ST) with HERCULES or EGA graphics cards. Figure 1 presents the historic pen-and-paper version of the questionnaire autographed by the first Polish cosmonaut, Maj. Mirosław Hermaszewski.

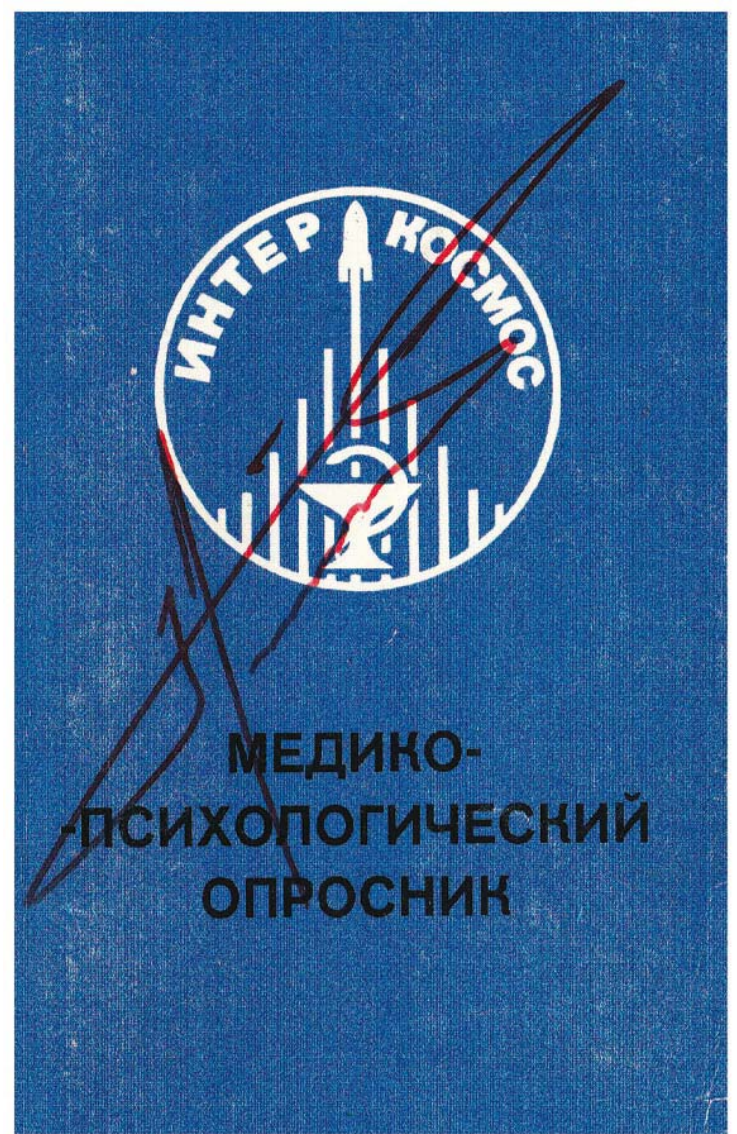

The research objective of the questionnaire was to collect information on 9 aspects of functioning during the space flight, namely: (1) collecting opinions to be used for individualization of the comfort of working and dwelling at the space station; (2) collecting information on the possibility to maintain the circadian sleep/activity cycles; (3) gathering cosmonauts' opinions on the conditions required to optimize the internal habitat of the space station; (4) collecting data on ergonomical use of space station interior; (5) the assessment of the usefulness of ground working habits in zero gravity conditions from the perspective of improving the ground training; (6) collection of data on the relationships between the international crew members and relationship with the ground flight control team; (7) gathering information on the functioning of the body in zero gravity conditions; (8) the assessment of the organization of active recreation; (9) the assessment of the usefulness of the on-board medicine box.

In line with the instructions, cosmonauts assessed numerous aspects of well-being in relation to individual stages of the flight using dychotomic

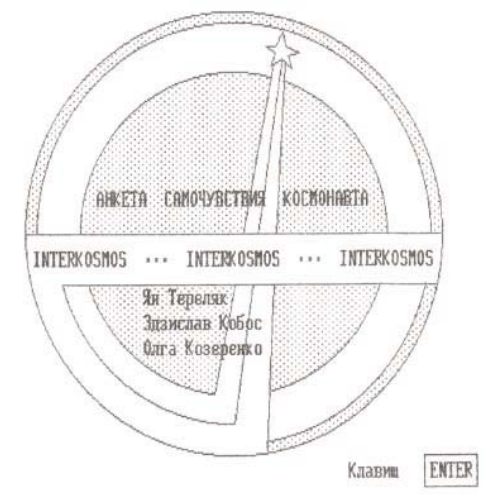

Iросим попать свой хоп (не более чем 3 щифры) и нахать ENTER

Fig. 1. Polish psychological questionnaire used during the space mission SALYUT 6 / SOYUZ 29, autographed by Cosmonaut Mirosław Hermaszewski. 
answer categories. Thus, in order to assess current well-being, subjects were to mark points corresponding to the following categories: satisfactory/ unsatisfactory, absent-minded/concentrated, inhibited/energetic, wavering/decided, relaxed/tense.

Subjective assessment of working conditions was based on the following categories: time devoted to work (little/satisfactory), workplace (uncomfortable/comfortable), freedom of movements (extremely restricted/unrestricted), working regimen (too demanding/ideal), lighting (too dim/comfortable), temperature (comfortable/too hot), humidity (comfortable/too dry), noise (low/too noisy).

The assessment of recreation included the following attributes: place to sleep (extremely uncomfortable/comfortable), place for recreation (extremely limited/comfortable), time for recreation (extremely short/excessive). The last category, i.e. "time for recreation" was supplemented by an additional instruction: "Assuming total recreation time to be $100 \%$, estimate the percentage of time devoted to: reading, listening to music, watching video, talking to family and friends, playing parlor games, sleeping, resting passively, lazing around".

The completion of tasks in line with the predefined schedule was assessed using the following categories: associated with mental fatigue (slightly/significantly), associated with physical fatigue (slightly/significantly), associated with haste (slight/significant), associated with interest (slight/ significant).

Assessment of motor functions included the following aspects: speed of motor reactions (very restricted/unproblematic), precision of movements (very limited/very good), hand coordination (very limited/very good).

The quality of sleep was assessed on the basis of following categories: time until falling asleep (too long/very short), getting enough sleep (not enough/enough), dreaming (no dreams/frequent dreaming).

The assessment of locomotion was based on the following categories: moving around the spaceship cabin (with much difficulties/with no difficulties), speed of moving around (with much difficulties/ with no difficulties).

Thinking and decision making was assessed on the basis of the following categories: understanding information from on-board sources (with much difficulties/with no difficulties), assessment of the safety of current situation (with much difficulties/ with no difficulties), occurrence of unpredicted situations (very rare/very frequent), feeling confused by unexpected situations (very frequently/never), necessity to continuously adapt to varying flight conditions (very rare/very frequent), illusions of various kinds (never/very frequent). Categories used to assess the appetite included: appetite (too weak/too strong), taste of food (not tasty/ very tasty).

After completion of the surveys, answers were sent to a database of limited graphical analysis allowing to simultaneously present the data from not more than four cosmonauts. The results of the studies conducted in a series of space experiments using the presented Cosmonaut Physical State Questionnaire in 12 international space crews at space stations Salyut 6, Salyut 7 and Mir were discussed in another paper [30] highlighting the usefulness of the obtained results in the analysis of the mechanisms of adaptation at different stages of the space flight as well as in space ergonomics recommendations to improve the dwelling and functioning conditions for cosmonauts [62], particularly in long-lasting space missions. The results triggered the development of a new model of psychological tests, bringing to the forefront the issues of resistance to stress, social isolation and sensory deprivation $[58,59,61]$.

\section{Studies at the natural laboratory of the Arctic and Antarctic Stations of the Polish Academy of Sciences}

Due to the plans to conduct long term flights to orbital stations as well as interplanetary flights, space psychology sought for experimental models useful for the studying of the mechanisms of adaptation to social isolation (seclusion) conditions and assessing psychological costs thereof. The broad literature on the subject suggested, besides laboratory experiments, the usefulness of natural analogs such as speleological expeditions, undersea exploration (underwater habitats), far sea voyages, submarines, polar expeditions and space missions. A detailed review of the subject is presented in the monograph by J. Terelak [56].

Thus, J.H. Earls [14] precisely described the syndromes of adaptation to isolation of a submarine ship in a 60-day military operational submersion: the "half-time submersion syndrome" (weeks 4-5) characterized by significantly depressed mood, reduced appetite, sleep disorders, closing in on oneself, etc., and the "final week syndrome" (week 8) characterized by mood swings. The author interpreted these symptoms in terms of psychological costs that are an evidence of an actual stress associated with isolation.

On the other hand, polar expeditions are associated with the necessity to stay in small task groups in extreme conditions. This pertains main- 


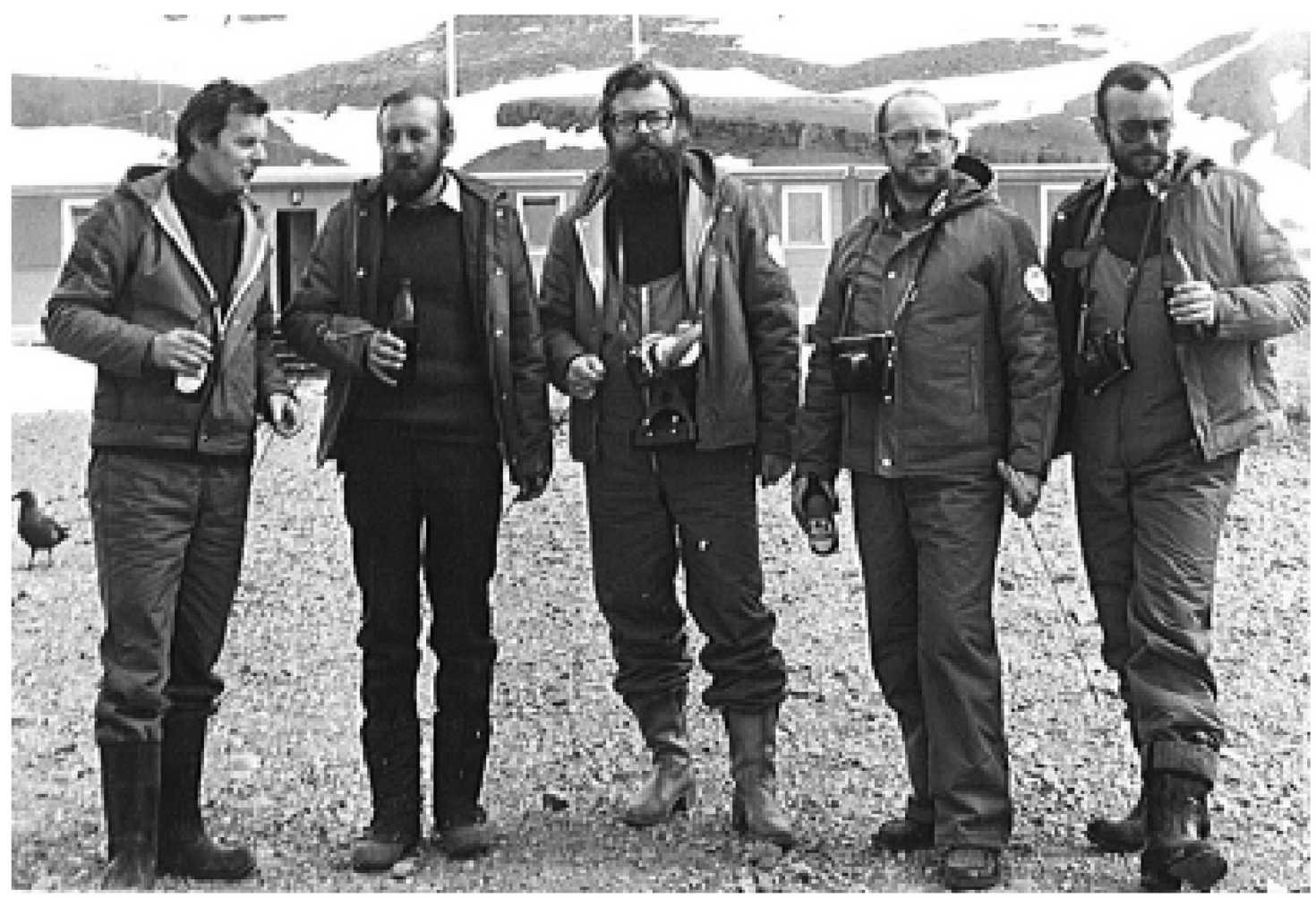

Fig. 2. Military Institute of Aviation Medicine representatives participating in the III and IV Antarctic expedition of the Polish Academy of Sciences 1978-1980. From left: Dr. Maciej Rembiszewski, PhD (head of the III winter camp), Asst. Prof. Andrzej Myrcha, PhD (head of the IV Antarctic expedition of the Polish Academy of Sciences), Dr. Jan Terelak, PhD (psychologist researcher from the Military Institute of Aviation Medicine, participant of the III Antarctic expedition - author of the article), Dr. Jacek Rożyński, MD, PhD (physician researcher from Military Institute of Aviation Medicine, participant of the IV Antarctic expedition of the Polish Academy of Sciences), Dr. Wojciech Nurkiewicz, MD (surgeon from the Ministry of National Defense, participant of the IV Antarctic expedition of the Polish Academy of Sciences).

ly to the research and meteorological stations in the Antarctica as the only uninhabited region of the planet, isolated from the rest of the world by a geographic barrier [32]. The characteristics of the stress-inducing factors of the Antarctic suggests that Antarctic seclusion is a special case of social seclusion as it includes both certain elements of sensory deprivation (white surroundings or long polar nights), monotony (repeating everyday rituals), confinement (staying mainly in closed rooms due to climatic reasons) as well as classical deprivation of information (limited access to information from the outside world) and deprivation of numerous basic physiological, psychological and sociological needs. Thus, Antarctic seclusion was considered to be a good analogue of task-oriented seclusion in spaceships, characterized by a deficit of emotional or social gratification $[56,71]$.

The first experiences of group flights in spaceships and orbital stations confirmed that besides the zero gravity conditions, examination of the ef- fect of long-term social isolation will become an important problem for space psychologists [15]. The experience of astronauts participating in longlasting space flights confirms that long-term social isolation generates stress [97].

This is also confirmed by the results of our own research conducted as part of the international research project by the Committee for Space and Satellite Research of the Polish Academy of Sciences, Military Institute of Aviation Medicine and Interkosmos at the Henryk Arctowski Memorial Antarctic Station of the Polish Academy of Sciences, consisting in the assessment of various aspects of psychophysiological costs of social isolation lasting one year $[32,79]$.

Among others, the effect of isolation stress on self-assessed cognitive processes and intellectual efficiency. The first aspect included three elements: assessment of self, assessment of others and assessment of current situation. Based on the semantic differential technique by Ch.E. Osgood, G.J. Suci and 
P.H. Tannebaum introduced in The Measurements of Meaning, patterns of connotational differentiation (evaluation, activity and potency) were assessed in relation to personal and professional categories such as "my wife", "my parents", "my children", "my principal", "my colleagues", "myself as a father", "myself as a man", "myself as a husband", "myself as an employee", "myself as a colleague".

The assessment was based on the assumption that the attitudes were tantamount to the evaluating dimension of the semantic space, i.e. to the placement of the subject of particular attitude at particular point of the 7-point semantic space scale. In relation to the evaluation dimension, following adjectives were used to describe the social concepts: good/bad, efficient/inefficient, tense/ relaxed, attractive/repulsive, false/true, rivaling/ cooperative, safe/threatened, wise/stupid, hostile/ friendly. No abstract terms were used. The dimension of potency was described by three pairs of adjectives: intense/non-intense, masculine/feminine, colorful/colorless. The dimension of activity was described by two pairs of adjectives: passive/active, cold/warm.

According to the instruction, subjects assessed the level to which particular adjective was relevant to a particular concept using a 7-point scoring scale (1 - not at all relevant, 4 - neutral, 7 - very relevant). Surveys were conducted once every three months during the yearly isolation period, at baseline (home) and at completion (on board of the ship going back home).

Among others, it was observed that attitudes towards the close ones left behind home shifted towards idealization of their image as isolation time increased. Idealization was not as evident in case of individuals who were less emotionally close to the subjects (e.g. "my principal", "my subordinate"). Similar tendencies were observed with regard to idealization of self ("myself as a father", "myself as a man", "myself as a husband").

The aforementioned data indicate an important cognitive aspect of reaction to stress manifesting, among others, by changes in the perception of self, other people as well as the stressful situation itself. The last problem was also a subject of a study using a list of 20 negative and 20 positive adjectives assigned to a 5-point scale [62]. The adjectives were used to evaluate current situation and the group. Assessments was made once every month during the yearly period of isolation, at baseline (home) and at completion (on board of the ship going back home). Both subjective and personal categories were perceived with increasingly negative attitudes as isolation time increased $[57,80]$.
The negative effect of isolation stress on intellectual efficiency as measured every two months during the yearly isolation period using the 1-hour Kraepelin test consisting of adding up pairs of numbers was also confirmed. Taking into consideration the percentage increase in proficiency that indicated percentage changes in the speed of intellectual work (determined as the index of difference between the initial and the final segments of the test), one could observed statistically significant deterioration of intellectual efficiency as isolation time increased. Ex post interpretation related the changes in intellectual efficiency to low activation of the brain as a behavioral effect of monotony, accompanied by a drop in motivation to take up efforts [96]. I describe the phenomenon from the observer's position in more detail in another study [67].

It is also worthwhile to comment on the results of the assessment of psychological stress associated with adaptation to long-lasting isolation from the standpoint of space psychology. Introversion (closing in one oneself) and neurotization were observed to progress as isolation time increased, with both changes being of only adaptational character as evidenced e.g. by the fact that the results stabilized back at baseline (pre-expedition) levels after coming back home.

Finally, interesting results were obtained with regard to other aspects of the mechanisms of adaptation to log-term social isolation conditions, namely to mood swings and aggressive behaviors increasing with the duration of seclusion [53]. The mechanism could be explained on the basis of the [34] optimum stimulation or [21] optimum activation theory that suggest that aggressive behaviors are sources of high stimulation that elevates decreased brain activation to optimum levels in seclusion and monotony conditions [76,93]. This has been confirmed by a study comparing a large and a small team of polar explorers staying for more than one year in Polish polar stations in the Arctic $(n=20)$ and the Antarctic $(n=8)$. The study showed that socially acceptable symptoms of aggressive behavior occurred sooner than in the more populated groups [91].

Summing up the presented results of studies conducted in natural conditions of social seclusion, it should be stated that the reported "winter-over syndrome", consisting of the symptoms developing as adaptation to long-term social isolation and sensory deprivation, such as reduced motivation to work, mood swings, introversion (closing in on oneself) and increased aggressive behaviors [58-60] may be a good theoretical 
model for predicting adaptational mechanisms in astronauts during long space flights, particularly during interplanetary flights.

The results of studies conducted in both the space station and in the conditions of the polar bases of the Polish Academy of Sciences in the Arctic (Spitsbergen) and the Antarctic (King George Island in South Shetland Islands and Bunger Oasis on mainland Antarctica) were presented at numerous international conferences as part of the Interkosmos Working Group Section of Space Biology, Medicine and Psychology $[3,4,63,65,66,75,76,81,83-85]$.

Extrapolation of the obtained results to activities associated with selection of candidates for long-term orbital and interplanetary space flights and the psychoprophylactics of the flights as such has found wide practical use and continuation in both laboratory conditions as in real-life space flights to orbit stations [24], as well as in interplanetary flights [16] and Mars programs $[36,48]$. The perspective of interplanetary flights [25] brings to the forefront the problems of ergonomic designs of space habitats $[19,43,62,72]$, stress coping strategies in cosmonauts $[49,95]$ as well as psychoprophylactics of sensory deprivation and social seclusion $[6,45,75,90]$ and the social interactions in international space crews [7,33], particularly in small task groups [27].

\section{DISCUSSION}

When concluding the presentation of Polish space psychology from both retrospective and prospective perspectives, it should be stated that further intensive development of worldwide space psychology is related with globalization of space research in both scientific and commercial aspects, conducted in both actual space flight conditions (Kanas, Salnitskiy, Ritsher et al., [28]; DeLaTorre, Baarsen, Ferlazzo, et al., [13]) and laboratory analogs of future planetary exploration missions (Horneck, Facius, Reichert, et al., [22]; Binsted, Kobrick, O'Griofa, et al., [51,55]; Tafforin, [51,55]). Space psychologists have also for long time been involved in prevention activities including psychological support to the members of space crews involved in long-lasting space flights, e.g. Yuri Romanenko [44], who was the first man to spend 326 days in a space station [17].

Research issues pursued by space psychology were also presented in popularization activities owing to the establishment of the Polish Astronautical Society, the scientific journal "Postępy Astronautyki" ("Advances in Astronautics") and the popular journal "Astronautyka" ("Astronautics") presenting worldwide achievements of all scientific disciplines contributing to space programs, including space psychology $[54,58-61,64,73,74,77,78]$. The Polish Astronautical Society was engaged in educational activities by holding lectures and conferences at local branches, patronized and supported by the Committee for Space and Satellite Research of the Polish Academy of Sciences, the Space Research Centre and the Military Institute of Aviation Medicine in Warsaw (Kwarecki, Terelak, 1980). Students of such universities as Cardinal Stefan Wyszyński University in Warsaw or the University of Social Sciences and Humanities have established scientific associations for aviation and space psychology [23]. These activities led not only to the establishment of scientific collaboration with the European Space Agency (ESA), but also the development of the Mars Society Poland (MSP), project, being a branch of the Mars Society promoting the idea of a manned mission and colonization of Mars by developing own projects as well as co-ordinating the Society's activities in Poland (e.g. the project of a manned vehicle MPV), participation in the "Red Rover Goes to Mars" contest, the "Spirit" and "Opportunity" rover steering program (JPL, USA), simulations ad MDRS and Flashline Arctic Research Station bases or by providing IT support to the design of Martian rovers "Magma", "Copernicus", "Scarab", and "Scorpio" as well as in the construction of a Polish Martian habitat.

\section{CONCLUSIONS}

1. The establishment and development of Polish space psychology has been associated with the historic event of the space flight of the first Pole in 1978.

2. Polish studies conducted in the natural environment of a space station as well as in the analogs of space conditions at polar bases of the Polish Academy of Sciences in the Arctic and the Antarctic were original in character and provided important contribution to worldwide literature on the subject.

3. Popularization of space psychology and astronautics in Poland has contributed to the increasing interest in space-related problems in different aspects of social life (technical, philosophical, educational, etc.). 


\section{AUTHORS' DECLARATION:}

Study Design: Jan F. Terelak; Data Collection: Jan F. Terelak; Manuscript Preparation: Jan F. Terelak; Funds Collection: Jan F. Terelak. The Author declares that there is no conflict of interest.

\section{REFERENCES}

1. Ambler, R.K., Berkshire, J.R., O'Connor, W.F. (1961) The identification of potential astronauts. Pensacola: Naval School of Aviation Medicine, Report No. 33.

2. Barański, S. (1977) (ed.). Medycyna lotnicza i kosmiczna. Warszawa: PZWL.

3. Barański, S., Kubiczkowa, J., Kwarecki, K., Terelak, J., Rosiek, O. (1985) Sprawozdanie z XVIII Sympozjum Interkosmos. Medycyna Lotnicza. 88 (3). 65-9.

4. Barański, S., Kubiczkowa, J., Rosiek, O., Sarol, Z., Skibniewski, F., Terelak, J. (1984) Sprawozdanie z XVII Konferencji Biologii i Medycyny Kosmicznej oraz Posiedzenia Grup Roboczych Interkosmos. Medycyna Lotnicza. 85 (4). $72-77$.

5. Binsted, K., Kobrick, R.L., O ' Griofa, M. et al. (2010) Human factors research as part of a Mars exploration analogue mission on Devon Island. Planetary and Space Science. 58. 994-1006.

6. Bishop, S.L., Kobrick, R., Battler, M., Binsted, K. (2010) FMARS 2007: Stress and coping in anarctic Mars simulation. Acta Astronautica. 66. 1353-67.

7. Boyd, J.E., Kanas, N., Gushin, V.I., Saylor, S. (2007) Cultural differences in patterns of mood states on board the International Space Station. Acta Astronautica. 61. 668-71.

8. Chaikin, A. (1985) The loneliness the long-distance astronaut. Discover. 2. 20-31.

9. Christensen, J.M., Talbot, J.M. (1986) A review of the psychological aspects of space flight. Aviation, Space and Environmental Medicine. 57 (3). 203-212.

10. Concertino, V.A. (2007) Space, Heath risks of. In G. Fink (ed.). Encyclopedia of stress. Second Edition (Vol. 3) (548-54). New York: Academic Press.

11. Connors, M.M., Harrison, A.A. (1985) Living aloft: Human requirements for extended space flight. NASA SP-483.

12. Cunningham, W. (1977) The all American boys. New York: McMillan.

13. DeLaTorre, G.G., Baarsen, B., Ferlazzo, F. et al. (2012) Future perspectives on space psychology: Recommendations on psychosocial and neurobehavioural aspects of human space flight. Acta Astronautica. 81. 587-99.

14. Earls, J.H. (1969) Human adjustment to an exotic environment. Arch. Gen. Psychiatry. 20. 117-23.

15. Eberhard, J.W., Smith, K.T. (1967) The problem of off duty time in long duration space mission: An annotated bibliography. McLean, Wirginia: Serendipity Associates, Vol. III.

16. Goswami, N., Roma, P.G., DeBoever, P., et al. (2012) Using the Moon as a high-fidelity analogue environment to study biological and behavioral effects of long-duration space exploration. Planetary and Space Science. 74. 111-20.

17. Grigorirv, A.J., Kozerenko, O.P., Myasnikov, W.I. (1987) Selected problems of psychological support of prolonged space flight. Washington: $38^{\text {th }}$ Congrss of the International Astronautical Federation AIAA. DC.

18. Gunderson, E.K.E. (1968) Mental health problem in Antarctica. Archines of Environmental Health. 17. 558-64.

19. Harrison, A.A. (2010) Humanizing outer space: Architecture, habitability, and behavioral health. Acta Astronautica. 66. 890-96.

20. Hartman, B.O. (1961) Time an load factors in astronaut proficiency. In: B.E. Flaherty (Ed.) Symposium of Psychophysiological Aspects of Space Flight (278-308). New York: Columbia University Press..

21. Hebb, D.O. (1965) Drives and the C.N.S., In: H. Fowler (Ed.): Curiosity and exploratory behavior New York: McMillan Co. 176-90.

22. Horneck, G., Facius, R., Reichert, M. et al. (2006) HUMEX, a study on the survivability and adaptation of humans to longduration exploratory missions, part II: Missions to Mars. Advances in Space Research. 38. 752-59.

23. Jędrych, A. (2013) Scientific activities of Aviation and Space Psychology Section of Cardinal Stefan Wyszyński University Psychology Students' Scientific Association. Polish Journal of Aviation Medicine and Psychology. (In Press).

24. Kalery, A.Y., Sorokin, I.V., Tyurin, M.V. (2010) Human space exploration beyond the international space station: Role of relations of human, machine and the"Earth". Acta Astronautica. 67. 925-33.

25. Kanas, N. (2011) From Earth's orbit to the outer planets and beyond: Psychological issues in space. Acta Astronautica. 68. 576-81. 
26. Kanas, N., Manzey, D. (2008) Space psychology and psychiatry. El Segundo (California): Springer.

27. Kanas, N., Harris, H., Neylan, T. et al. (2011) High versus low crew member autonomy during a 105-day Mars simulation mission. Acta Astronautica. 69. 240-44.

28. Kanas N., Salnitskiy, V.P., Ritsher J.B. et al. (2006) Human interactions in space: ISS vs. Shuttle/Mir. Acta Astronautica. 59. 413 - 19.

29. Korchin, S.J., Ruff, G.E. (1964) Personality characteristics of the Mercury astronauts. In G.H. Grosser, H. Wechsler, M. Greenblatt (Eds.) The threat of impending disaster. Cambridge, Mass.: MIT Press.

30. Kozerenko, O.P., Radkowski, G., Terelak, J., Mikshik, O. (1991) The problem of man's psychic adaptation under the spaceflight conditions. In K. Boda and V.M. Baranov (Eds.). Current Trends in Cosmic Biology and Medicine, Slovak Academy of Sciences, Ivanka Pri Dunaji (CSRF), Vol. 2, 91-94.

31. Kwarecki, K., Terelak, J. (1980) Medycyna i psychologia kosmiczna. Warszawa: Wiedza Powszechna “Omega”.

32. Kwarecki, K., Terelak, J. (1981) Problem of human biology in Polish polar research. Postępy Astronautyki. 14 (3). $35-41$.

33. Lapierre, J., Bouchard, S., Martin, T., Perreault, M. (2009) Transcultural group performance in extreme environment: Issues, concepts and emerging theory. Acta Astronautica. 64. 1304-13.

34. Leuba, C. (1965) Toward some integration of learning theory: The concept of optimal stimulation. In H. Fowler (Ed.): Curiosity and exploratory behavior. New York: Macmillan Co. 169-75.

35. Link, M.M., Gurovski, N.N., Brianov I. (1975) Otbor kosmonawtow. In O.G. Gazenko and M. Kalvin (Eds.) Osnowy kosmiczeskoj biołogii i mediciny (419-38). Moskwa: Nauka.

36. Manzey, D. (2004) Human missions to Mars: New psychological challenges and research issues. Acta Astronautica. 55. $781-90$.

37. Miasnikov, W.I., Novikov, M.A., Kozerenko, O.P., Uskov, F.N. (1972) Psichołogiczeskije aspekty otbora i komplektowania ekipażej kosmiczeskoj karablej. In R.B. Striełkov (Ed.) Kosmiczeskaja biołogia i awiakosmiczeskaja medicina. Moskwa: Nauka.

38. Migdał, K., Terelak, J. (1990) Selective attention and psychomotor performance, In K. Boda (Ed.). Current trends in Cosmic Biology and Medicine, Slovak Academy of Sciences, Ivanka Pri Dunaji (CSRF), Vol. 1, 91-96.

39. Novikov, M.A., Izosimov, G.W., Gerasimowicz, A.A. (1977) Sredstwia optimizacji grupowogo wzaimodiejstwia w usłowiach dlitielnoj izolacji. In W.M. Czernigowski (Ed.) Problemy kosmiczeskoj biologii (200-216). Moskwa: Nauka.

40. Oberg, J.E. (1981) Red star in orbit. New York: Random House.

41. Oberg, J.E. (1983) Crisis in orbit for the USRR. New Scientist. 100 (9). 385-88.

42. Project Merkury (1959) Man-In-Space Program of the National Astronautics and Space Administration. Washington, D.C.

43. Roma, P.G., Hursh, S.R., Hienz, R.D. et. al. (2011) Behavioral and biological effects of autonomous versus scheduled mission management in simulated space-dwelling groups. Acta Astronautica. 68. 1581-88.

44. Romanienko, J. (1988) Man who holds the record in space says there's no limit. San Francisco Chronicle. 21 (1).

45. Schneider, S., Brümmer, V., Carnahan, H. et al. (2010) Exercise as a countermeasure to psycho-physiological deconditioning during long-term confinement. Behavioural Brain Research. 211. 208-14.

46. Solomon, P. (1961) Motivations and emotional reactions in early space flights. In B.E. Flaherty (Ed.) Psychophysiological aspects of space flight (272-77). New York: Columbia University Press.

47. Strange, R.E., Klein, W.J. (1974) Emotional and social adjustment of recent U.S. winterower parties in isolated Antarctic station. Chicago: Polar Human Biology Proceedings of the SCAR/IUPS/IUBS Symposium on Human Biology and Medicine in Antarctic.

48. Suedfeld, P. (2010) Historical space psychology: Early terrestrial explorations as Mars analogues. Planetary and Space Science. 58. 639-45.

49. Suedfeld, P., Brcic, J., Legkaia, K. (2009) Coping with the problems of space flight: Reports from astronauts and cosmonauts. Acta Astronautica. 65. 312-24.

50. Szczechura, J., Terelak, J., Kobos, Z., Pińkowski, J. (1998) Occulographic assessment of workload influence on flight performance. International Journal of Aviation Psychology. 8 (2). 157-76.

51. Tafforin, C. (2013) The Mars-500 crew in daily life activities: An ethological study. Acta Astronautica. 91. 69-76.

52. Tarnowski, A., Terelak, J., Truszczyński, O. (1997) Special training influences on postural body control of pilot's candidates, In: Proceedings of the 33rd International Applied Military Psychology Symposium, May 12-16.1997, Vienna (Austria).

53. Terelak, J.F. (2011) Aggression as a source of stimulation in experimental situations of sensory deprivation and social isolation. in: J.F. Terelak, Z. Majchrzyk (Eds.) Psychology of Aggression. Selected Issues. (51-72) Warsaw: Uniwersity Cardinale Stephani Wyszynski in Warsaw. 
54. Terelak, J. (1976) Alpha index and personality traits in pilot. Aviation Space and Environmental Medicine. 47 (2). $133-136$.

55. Terelak, J. (1991) Current research and trends in Aviation Psychology in Poland. Aviation, Space and Environmental Medicine. 62 (9). 903-908.

56. Terelak, J. (1982) Człowiek w sytuacjach ekstremalnych: Izolacja antarktyczna. Warszawa: Wyd. MON.

57. Terelak, J. (1985) Dinamika nieformal'noj struktury malej celewoj gruppy w jestestwiennych uslowiach stressa obszczestwiennoj izolacji. Kosmiczeskaja Biologia i Awiakosmiczeskaja Medicina. 19 (6). 90-92.

58. Terelak, J. (1980) Efekty psychologiczne izolacji kosmicznej (I). Astronautyka. 4. 23-24.

59. Terelak, J. (1980) Efekty psychologiczne izolacji kosmicznej (II): Badania w okrętach podwodnych. Astronautyka. 5. $19-20$.

60. Terelak, J. (1980) Efekty psychologiczne izolacji kosmicznej (III): Badania w strefach polarnych. Astronautyka. 6. 12-14.

61. Terelak, J. (1981) Efekty psychologiczne izolacji kosmicznej (IV): Badania w symulowanych warunkach lotu kosmicznego. Astronautyka. 1. 12-13.

62. Terelak, J. (1988) Ergonomia a bezpieczeństwo pracy w statkach powietrznych i kosmicznych. Ergonomia, 21 (1).

63. Terelak, J. (1990) Field dependence-independence and the eye-hand-legs coordination. Perceptual and Motor Skills. 71. 947-950.

64. Terelak, J. (1978) “Głód zmysłów” jako problem długotrwałych lotów kosmicznych. Astronautyka. 4. 20-22.

65. Terelak, J. (1986) Gruppowaja dinamika i effektiwnost' diejatiel'nosti w ekstremal'nych uslowiach. Kosmiczeskaja Biologia i Awiokosmiczeskaja Medicina. 20 (6). 82-83.

66. Terelak, J. (1990) Individual differences of anxiety level and psychomotor performance. Personality and Individual Differences. 11 (8). $771-75$.

67. Terelak, J. (1982) Introspekcje antarktyczne: Diariusz III Wyprawy Antarktycznej PAN i zimowania-1979 na Polskiej Stacji Antarktycznej im. Henryka Arctowskiego. Warszawa: Wyd. MON.

68. Terelak, J. (1987) Kierunki badań w polskiej psychologii lotniczej i kosmicznej. Przegląd Psychologiczny. XXX 4. 955-975.

69. Terelak, J. (1980) “Koszty psychologiczne” długotrwałej izolacji w strefach polarnych. (Badania empiryczne na Stacji PAN im. H. Arctowskiego). Medycyna Lotnicza. 69 (4). 16-24.

70. Terelak, J. (1976) Ludzie Kosmosu. Astronautyka. 6. 17-19.

71. Terelak, J. (1984) Niekotoryje psichologiczeskije posledstwija prodolzitielnoj socjalnoj izolacji. Kosmiczeskaja Biologia i Awiakosmiczeskaja Medicina. 18 (2). 54-56.

72. Terelak, J.F. (2004) Problemy symulowania "sztucznego środowiska" habitatu z perspektywy sozopsychologii kosmicznej. Studia Ecologiae et Bioethicae. 2 (2). 575-94.

73. Terelak, J. (1983) Przygotowanie i trening naziemny kosmonautów. Astronautyka. 1983. 129 (5). 8-11.

74. Terelak, J (1988) Psychologia kosmiczna w Polsce. Astronautyka. 4. 16-17.

75. Terelak, J. (1995) Psychologiczne efekty stresu ekstremalnego związanego z niedoborami stymulacji. Ergonomia. 2. 245-258.

76. Terelak, J. (1983) Psychologiczny mechanizm zachowań agresywnych w sytuacji długotrwałej izolacji małej grupy zadaniowej. Medycyna Lotnicza. 78 (1). 28-30.

77. Terelak, J. (1979) Psychologiczne problemy lotów kosmicznych. Przegląd Wojsk Lotniczych i Wojsk Obrony Powietrznej Kraju. 4. 62-64.

78. Terelak, J. (1979) Psychologiczne problemy długotrwałych lotów kosmicznych. Przegląd Wojsk Lotniczych i Wojsk Obrony Powietrznej Kraju. 10. 55-58.

79. Terelak, J. (1985) Reakcje psychofizjologiczne człowieka w warunkach deprywacji sensorycznej i izolacji socjalnej. Acta Physiologica Polonia. 36.(2). Sup. 28. 138-60.

80. Terelak, J. (1986) Sprawozdanie z obrad Sekcji Psychologii Kosmicznej w ramach Konferencji Biologii i Medycyny Kosmicznej INTERKOSMOS (27.05-1.06.1985, Gagra - ZSRR). Postępy Astronautyki. 19 (1-2). 153-57.

81. Terelak, J. (1987) Sprawozdanie z Sekcji Psychologii Kosmicznej obradującej w ramach XIX Konferencji Biologii i Medycyny Kosmicznej oraz posiedzeń grup roboczych “Interkosmos”. Hawana (Kuba), 5- 12.IV.1986. Przegląd Psychologiczny. XXX 3. 793-95.

82. Terelak, J. (1983). Sprawozdanie z udziału w obradach Sekcji Psychologii Kosmicznej XVI Konferencji INTERKOSMOS, Keczkemet (Węgry) 19-25.06.1983. Postępy Astronautyki. 17 (1). 95-102.

83. Terelak, J. (1990) Sprawozdanie z Sympozjum Sekcji Psychologii Kosmicznej w ramach XXII Konferencji Biologii i Medycyny Kosmicznej oraz posiedzenia grup roboczych programu “Interkosmos”, Varna (Bułgaria) 14-19.05.1989. Przegląd Psychologiczny. XXXIII 1. 274-76. 
84. Terelak, J. (1990) Sprawozdanie z Sympozjum Sekcji Psychologii Kosmicznej w ramach XXIII Konferencji Biologii i Medycyny Kosmicznej w Koszycach, CSFR (20-26.05.1990). Medycyna Lotnicza. (3-4). 108-109, 114-115.

85. Terelak, J. (1988) Sprawozdanie z XX Konferencji Biologii i Medycyny Kosmicznej “Interkosmos” (Berlin, 18-22.05.1987). Postępy Astronautyki. 21 (1-2). 205-207.

86. Terelak, J. (1989) Trends in Poland in Space Psychology Research. Aviation, Space and Environmental Medicine. 60 (4). 352-60.

87. Terelak, J. (1994) Współczesne problemy psychologii lotniczej i kosmicznej: Aspekty ergonomiczne. Ergonomia, 17 (1). $79-100$.

88. Terelak, J., Błoszczyński, R. (1978) Problemy doboru i selekcji psychologicznej kosmonautów. Medycyna Lotnicza. 59. $18-27$.

89. Terelak, J., Jachnis, A. (1994) Characteristics of temperament and thinking as related to psychomotor efficiency in stress. Personality and Individual Differences. 16 (6). 989-991.

90. Terelak, J., Kwarecki, K., Rakusa-Suszczewski, S. (1978) Deprywacja sensoryczna i izolacja społeczna jako problemy psychologii kosmicznej (Eksplikacje badań antarktycznych i eksperymentalnych). Postępy Astronautyki. 33 (2). 7-31.

91. Terelak, J., Maciejczyk, J. (1989) Some indicators of level of adjustment to extreme conditions of existence in the Arctic and Antarctic. Polish Psychological Bulletin. 20 (3). 26-31.

92. Terelak, J., Maciejczyk, J. (1985) Wlianie stressa ugrozy na psichomotornuju ustoicziwost' letczikow s raznym urowniem trewoznosti. Kosmiczeskaja Biologia i Awiakosmiczeskaja Medicina. 19 (4). 24-26.

93. Terelak, J., Ruta, A. (1982) Stymulacyjny mechanizm adaptacji człowieka do sytuacji derywacji sensorycznej. Postępy Astronautyki. 15 (4). 19-28.

94. Terelak, J., Truszczyński, O. (1992) Psychologia kosmiczna i astronautyka. Astronautyka. 1-2. 178-179.

95. Terelak, J., Truszczyński, O. (1992a) Stres w długotrwałym locie kosmicznym. Przegląd Psychologiczny. XXXV 1. 91-100.

96. Terelak, J., Turlejski, J., Szczechura, J., Rożyński, J., Cieciura, M. (1985) Dynamics of simple arithmetic task performance under Antarctic isolation. Polish Psychological Bulletin, 16 (2). 123-128.

97. Vakoch, D. (Ed.) (2011). Psychology of space exploration: Contemporary research in historical perspective. Washington, DC: NASA.

98. West, J.B. (2000). Historical perspectives: Physiology in microgravity. Journal of Applied Physiology. 89. 379-84.

Cite this article as: Terelak JF: The Emergence and Development of Space Psychology in Poland. The Significance of the Historical Space Flight of Mirosław Hermaszewski. Pol J Aviat Med Psychol, 2013; 19(3): 23-36. 